\title{
Analysis of Macroeconomic Factors and Fundamental Factors to Sharia Stock Return on Trade, Services and Investment Sector Companies in Jakarta Islamic Index (JII) Period 2014-2018
}

\author{
Siti Fathimah Nurul Hasanah*, Ratih Hadiantini and \\ Aninthitha Putri Kusumawardhani
}

Faculty of Economics and Business, Universitas Informatika dan Bisnis Indonesia, Bandung, Indonesia

*Corresponding author. E-mail: sitifnh18@gmail.com

\begin{abstract}
This research aims to find out how much macroeconomic factors indicated by variable Inflation rate and Interest Rate (BI Rate) and fundamental factors indicated by market capitalization, Price Earning Ratio (PER) and Price Book Value (PBV) affect to Sharia Stock Return of trade, services and investment sector companies in JII during the period 2014-2018. The method in this research is quantitative and descriptive research methods. The populations in this study were companies in the trade, services and investment sectors in JII using purposive sampling technique, namely sampling with the criteria of companies that routinely distribute dividends during the study period. Multiple correlation tests shows the $\mathrm{R}$ value of 0.824 , This means that variables in macroeconomics and variables in company fundamentals have an effect of $82.4 \%$ on stock returns with a very strong correlation level. The value of the coefficient of determination indicates the inflation rate, BI Rate, market capitalization, PER and PBV can explain the return variable of 50.1\%, while $49.9 \%$ is explained by other variables outside the research model. The results show that partially the inflation rate and the BI Rate have a positive and insignificant effect on sharia stock returns, while market capitalization has a positive and significant effect, PER has a positive and significant effect and PBV has a significant negative effect on Islamic stock returns. Simultaneously the inflation rate and interest rate (BI Rate), market capitalization, Price Earnings Ratio (PER) and Price Book Value (PBV) have a significant effect on sharia stock returns of trade, services and investment companies in JII during the period 2014-2015. This means that Islamic investors are advised to further analyze the company's fundamental factors before investing in Islamic instruments, because the investment in Islamic instruments has anticipated economic factors, so the return on Islamic stocks tends to be smaller than conventional stock returns.
\end{abstract}

Keywords: Inflation Rate, Interest Rate (BI Rate), Market Capitalization, PER, PBV, Sharia Stock Return, JII

\section{INTRODUCTION}

The development of the Indonesian Islamic capital market began with the presence of the Jakarta Islamic Index (JII) on July 3, 2000, which aims to guide investors who wish to invest their funds in sharia. With the presence of this index, investors have been provided with stocks that can be used as a means of investing with the application of sharia principles [1]. Getting a return is the main reason investors invest funds in shares in a company.
Investors invest their funds in the hope of getting a return in the form of ownership, capital gains or dividends. The investing in the stock exchange is a type of investment with relatively high risk even though it promises relatively large returns [2].

One of the most popular Islamic capital market investment instruments today, namely Islamic stocks, now with an increasing number of people who are aware of the importance of investing for the future and also public 
awareness of investments in accordance with Islamic law for Muslim communities, public interest in Islamic stocks is also experiencing enhancement. The following is the development data in the percentage of the number of sharia-based stock investors for five years.

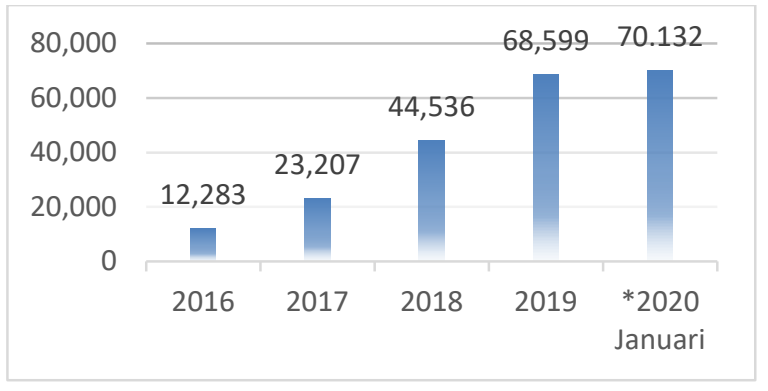

Figure 1 Number of Investor Sharia Shareholders

The growth shown in Figure 1 shows that there was a significant increase from 2016 which only amounted to 12,283, which almost doubled in 2017 and increased to 44,536 throughout 2018 then increased by 24,036 to 68,599 in 2019, until January 2020 it had reached 70,132 a person who has chosen sharia shares as an investment instrument, so that the funds that have been accumulated in sharia shares have amounted to IDR. 3,744 trillion. This can be considered as an initial indication of the potential size of beginner investors in Islamic stock instruments in Indonesia because it will continue to grow.

As an investment commodity that is classified as a high risk category, the shares of publicly traded companies are sensitive to changes that occur, both external changes such as in the economic, monetary, political, law and internal changes originating from the company itself [3]. Therefore, for beginner investors who are just starting to invest in stocks, it is better if they choose issuers through the company's fundamental analysis, because this is safer and relatively easy to learn [4].

In addition, to minimize the risks that will be faced in order to obtain optimal returns or profits, an investor needs to have expertise in processing various development news in macroeconomics and understanding the stock performance of a company. Then, choosing the right investment index also affects the risks that will occur. Currently, sharia-based investment, namely the Jakarta Islamic Index (JII) which consists of 30 Islamic stock issuers, is the most liquid index listed on the Indonesia
Stock Exchange (IDX) and has a large market capitalization which can be used as a safe and profitable investment option. .

Table 1 shows the problems faced relating to the development of returns per share of companies in the trade, services and investment company sector in JII, namely fluctuations that have experienced a downward trend in company stock returns through dividends distributed during the 2014 to 2018 period. Tunnel 1 shows that in 2014 to 2015 the AKR Corporindo and United Tractors companies experienced a significant decline while 2015 to 2016 was still relatively stable and increased in value again in 2017 , while the most volatile but not too significant from 2014 to 2017 was Surya Citra Media, but all companies in 2018 it experienced a very sharp decline compared to the previous year.

Lots of macroeconomic factors that influence stock price movements both nationally and internationally which result in stock returns. That as an economic instrument, the capital market cannot be separated from various kinds of environmental influences, both the economic environment and the non-economic environment [5]. The macroeconomic environment tends to have a strong influence on the performance of a capital market. The expected cash flows and required returns determine the value of the investment so that these matters are strongly influenced by the macroeconomic environment. The ability of investors to predict macroeconomic conditions that will occur in the future is very useful in making investment decisions, so investors need to consider macroeconomic issues, namely interest rates, inflation rates.

Inflation is one of the macroeconomic factors that affect stock price movements which will affect stock returns. The COVID-19 pandemic which began to emerge in early 2020 in China and has spread to various countries, including Indonesia, affected Indonesia's economic growth in the first quarter of 2020 which was recorded at $2.97 \%$ (year on year - yoy) which is slowing down when compared to with the previous quarter's achievement of $4.97 \%$ (yoy). The COVID-19 pandemic has an impact on various aspects of the economy in Indonesia, one of which is inflation. Bank Indonesia recorded a decline in household consumption in the first quarter of 2020 by $2.84 \%$ (yoy), much lower than the performance in the fourth quarter of 2019 of $4.97 \%$ (yoy). Investment also grew slowly by 1 .

Table 1. Dividends Distributed by Companies in the Trade, Service and Investment Sector Registered in JII Per Share.

\begin{tabular}{llccccc}
\hline Company & & 2014 & 2015 & 2016 & 2017 & 2018 \\
\hline AKR Corporindo & Dividend (IDR) & 130.00 & 120.00 & 120.00 & 200.00 & 148.35 \\
United Tractors & Dividend (IDR) & 935.00 & 691.00 & 143.00 & 1.303 .00 & 365.00 \\
Surya Citra Media & Dividend (IDR) & 70.00 & 83.00 & 73.00 & 75.00 & 20.00 \\
\hline
\end{tabular}


Based on the official statement www.bi.go.id, the inflation rate in Indonesia is still under control at a low and stable level. The annual inflation rate of the Consumer Price Index (CPI) is an indicator that is often used to measure the rate of inflation by calculating the average price change of goods and services for household consumption in February 2020, which was recorded at $2.98 \%$ (yoy), a slight increase compared to the previous year in in the same month of $2.57 \%$ (yoy), then decreased by $2.96 \%$ in March 2020 and decreased by $2.67 \%$ (yoy). This inflation can be said to be under control because it is lower than the 2020 inflation target set by Bank Indonesia previously, namely in the range of $3 \% \pm 1 \%$ in 2020 and 2021. The low level of inflation is influenced by weakening demand and the availability of a sufficient supply of goods and food, and the distribution chain is maintained as a result of the various steps to deal with the COVID-19 pandemic, where humans have activities that are lower than usual or there is a limitation on mobility because there are regulations at home. The results of their research on ref [6], that inflation has a negative and significant effect on stock returns. This means that if inflation has increased, then stock returns have decreased or vice versa. This research is different from research on ref [7], which resulted in the conclusion that inflation has no significant effect on stock returns.

The interest rate is often one of the factors that are considered when making investment decisions, whether long-term or short-term, a negative signal to stock prices can be obtained from high interest rates. Low interest rates will stimulate investment and economic activity, thus impacting on an increase in stock prices, conversely, if interest rates continue to increase, it will cause an increase in interest rates indicated for investing in stock instruments, so that it can influence investors' decisions to withdraw their investment in these stocks and prefer to move it to investments in the form of savings or deposits [8]. In their research on ref [9], state that it is partially obtained that the interest rate has a significant positive effect on stock returns of manufacturing companies on the IDX. Meanwhile, the conclusion is that partially the interest rate does not have a negative and significant effect on stock returns in the property sector listed on the IDX [9].

Apart from being seen from the macroeconomic condition, capital market analysis approach that is commonly used by investors or shareholders to be able to find out information and estimate the expected return on stock through a fundamental analysis approach which is generally used to predict stock price movements on the stock exchange. . The price movement of a stock is often a determining factor for the return (rate of return) in investing in stock instruments.

There is a market value ratio that can be used to provide an overview of conditions that occur in the market so that investors know the share price of a company against profit. argues, for investors, profit growth is expected to increase along with the higher value of the price earning ratio [10]. stated that the Price Earning Ratio (PER) has a significant negative effect on returns, this indicates that from the investor's point of view each increase in PER will cause a decrease in stock returns [11].

Price to Book Value (PBV), which is a ratio of market value, is often used in estimating the rate of return that investors will get. Because the PBV ratio of a company describes how much the company's ability to achieve company goals to create good corporate value and describes the level of welfare of the company's shareholders. On 18-19 May 2020 Bank Indonesia through the Board of Governors Meeting (RDG) decided to keep the BI 7-day Reverse Repo Rate (BI7DRR) at $4.50 \%$, the Deposit Facility rate at $3.75 \%$ and the Lending Facility rate at $5.25 \%$ which remains the same as the previous month considering the need to maintain external stability amid the current high level of global financial instability. Bank Indonesia realizes that there must be a policy to encourage economic growth, because there is potential for a reduction in interest rates with inflationary pressures. This policy indicates that the government is striving to ensure that investment in various instruments remains attractive, because it is consistent with low inflation forecasts and supports economic stability, which is on the target set by maintaining attractive returns on investment in domestic financial assets. Amid the slowing global economic conditions due to the impact of the COVID-19 pandemic, this policy is considered a preventive step to boost domestic economic growth. Bank Indonesia together with the government and related authorities strives to maintain the stability of the Indonesian economy by stimulating domestic demand.

This means that through a decision issued by the government in the RDG, it shows that the government is trying to increase investor interest in investing by obtaining optimal returns. In general, investors will see companies with large market capitalizations as long-term investments because they are seen as having the ability to pay dividends with relatively high risk exposure [12]. The uncertainty of the return that will be obtained, one of which can be represented by the share price and stock capitalization value of an issuer company [13].

\section{LITERATURE REVIEW}

\subsection{Financial Management}

Financial management is a combination of science and art aimed at studying how a financial manager uses all company resources to raise funds, manage funds, and share funds with the aim of being able to generate profits or create prosperity. For shareholders and maintaining business sustainability for the company [14]. 


\subsection{Irving Fisher's Saving Investment Theory}

Fisher assumes that the result of the interaction of the two forces of people's "time preference" for current capital and the investment opportunity principle (investing in current income will generate greater income in the future). Fisher defines that over time, capital as an asset that generates an income stream, the income stream differs from the share of capital that is generated, even though the two are linked by the interest rate. In particular, he said that the value of capital is the present value of the (net) income streams that the asset generates. The Fisher Effect or interest rate theory put forward by Irving Fisher in 1911 revealed that the supply of savings and the demand for capital is determined at this time and future prospects through investment opportunities.

\subsection{Signalling theory}

Fahmi (2016) said that signaling theory is a theory that discusses investors' responses to both negative and positive signals from a stock, because it will affect investment decisions, including explaining the ups and downs of prices in the market [14]. Investors will react in various ways when responding to these signals, such as not reacting to anything such as "wait and see" or waiting and seeing developments and then taking action whether to hunt down shares that are sold or wait and see. The 'wait and see' decision is seen as an investor's reaction to avoid the emergence of a much bigger risk caused by market factors that have not yet been profitable.

\subsection{Return of Sharia Shares}

The return (profit) obtained through Islamic stock investment is the difference between the selling price and the purchase price and dividends [15]. The difference between the selling price and the positive buying price indicates that the investor is getting capital gains or investment profits. Dividends are obtained by investors if the company sets aside a portion of the company's profits to be given to shareholders. Usually dividends are distributed periodically and with the approval of the General Meeting of Shareholders (GMS) and reported to the regulator. Usually companies that regularly distribute dividends are one of the investment references in buying shares. If the profit of investing in Islamic stocks is calculated by the inflation rate, then the profit is called the real return.

The sharia stock return formula can be seen in equation (1)

$$
R_{i t}=\frac{\mathrm{P}_{t}-\mathrm{P}_{t-1}}{\mathrm{P}_{t-1}} \times 100
$$

Information:

$\mathrm{R}_{\text {it }}:$ Return

$\mathrm{P}_{\mathrm{t}} \quad$ : Share Price This Year

$\mathrm{P}_{\mathrm{t}-1}$ : Previous Year's Share Price

\subsection{Inflation Rate}

Generally it is important for investors to reduce inflation, because the relatively increase in inflation will give a negative signal for investors in the capital market [14]. The reason is that inflation can specifically increase the company's revenue and costs, if the increase in production costs is higher than the price increase that can be enjoyed by the company, it indicates that the company's profitability will decrease (25-26). The formula consumer price index can be seen in equation (2)

$$
\mathrm{CPI}=\frac{\mathrm{Pn}}{\mathrm{P} 0} \times 100
$$

Information:

$$
\begin{aligned}
& \text { CPI = Consumer Price Index } \\
& \text { Pn = Current price } \\
& \text { P0 = Prices during the base year }
\end{aligned}
$$

\subsection{Interest Rates}

The interest rate (BI rate) is determined by the Board of Governors Meeting (RDG) which is conducted periodically using the BI7DRR (BI 7 Day (Reverse) Repo Rate) system accessed through www.bi.go.id. The interest rate itself is the percentage of income that comes from savings, deposits or the percentage of the amount that must be paid when making a loan within a certain period of time, where the rise and fall of interest rates will affect people's decisions in allocating funds, the bank interest rate tends to decrease causing the public will use the funds they have to buy shares.

\subsection{Market Capitalization}

Shares with a small market capitalization (small capitalization stock) on the Indonesia Stock Exchange are a market capitalization value that is below 1 trillion rupiah [16]. Although there is no standard measure that regulates when a stock is classified as small cap or big cap, most investors in the capital market agree that a market capitalization value of less than one trillion is classified as small cap stocks. Market capitalization value is obtained from multiplying the number of shares outstanding in the market by the price per share on that day. Typically, big cap stocks will be much more liquid than small cap stocks. 
However, it is not uncommon for small cap stocks to have promising growth prospects in the future compared to big cap stocks. The formula market capitalization can be seen in equation (3)

$$
\mathrm{Vs}=\mathrm{Ps} \times \mathrm{Ss}
$$

Information:

Vs = Market Capitalization Value

Ps $=$ Market Price $/$ Share Price

Ss $=$ Number of Shares Issued

\subsection{Price Earning Ratio (PER) or Price Profit Ratio}

In ref [14], states that the higher the Price Earning Ratio, the expected profit growth will also increase for investors. Price Earning Ratio (ratio of price to profit) is a comparison between the market price per share (market price per share) and the value of earnings per share (profit per share). The price earning ratio and price book value formulas can be seen in equation (4)

$$
\mathrm{PER}=\frac{\text { MPS }}{\mathrm{EPS}}
$$

Information:

PER $=$ Price Earning Ratio

MPS $=$ Market Price Per share or market price per share

EPS = Earning Per share or earnings per share

\subsection{Price Book Value (PBV) or Book Value Ratio}

PBV is an indicator that measures the market value through the current share price against the book value obtained through the calculation of the market value per share divided by the book value per share. The market value is also called the stock market price. Meanwhile, the company's book value is the company's assets minus the company's debt. The formula price book value can be seen in equation (5)

$$
\mathrm{PBV}=\frac{\text { Market Price per share }}{\text { Book Value per share }}
$$

Usually the lower PBV value (compared to industry) indicates that the company's stock is undervaluated (below its true value) or is considered a cheap stock and worth buying. PBV is called low or shows a cheap share price if the PBV value is below the number one, whereas if the opposite occurs, the value is above one, then the shares are said to be too expensive, and it is not advisable to buy them [15].

\section{METHODOLOGY}

The research method used by the author in this study is quantitative research methods. Quantitative research is a process of determining knowledge using information in the form of numbers as a tool to explain what researchers want to know [17]. The author conducted a quantitative descriptive study. The descriptive research often explains the relationship between variables by giving a clearer picture of the situation through focusing on certain aspects.

\subsection{Population and Sample}

Population is a generalization domain consisting of subjects or objects that have certain characteristics and qualities according to the criteria that match the research needs, and conclusions will be drawn [18]. The population in this study are trade, services and investment sector companies listed on the Indonesia Stock Exchange (IDX), especially those listed on the Jakarta Islamic Index (JII) index during the 2014 - 2018 period, namely AKR Corporindo Tbk, Matahari Department Store Tbk, Surya Citra Media Tbk and United Tractors Tbk. The sampling technique in this study using purposive sampling technique. Purposive sampling is a technique in which the data that enters the sample is based on the researcher's own considerations, where the sample is taken with specific aims and objectives in accordance with the information needed by the researcher who best represents the research. Therefore, the researchers set the following criteria:

1. Trade, services and investment sector companies listed on the Jakarta Islamic Index (JII) in the 2014-2018 periods.

2. Trade, services and investment sector companies listed on the Jakarta Islamic Index (JII) that routinely distributed dividends during the 2014-2018 period.

3. Trade, services and investment sector companies listed on the Jakarta Islamic Index (JII) that have complete data on PER, PBV and market capitalization required to support this research for 5 consecutive years.

Based on the above criteria, the total sample of companies is three companies with research years during the 20142018 periods (five years), so that the final sample is 15 samples. There is one company that does not meet the criteria, namely Matahari Department Store Tbk, on the grounds that the company does not routinely distribute dividends to shareholders during the study period, namely 2014 to 2018. Matahari Department Store Tbk does not distribute dividends in 2014 and 2018, then from that the company does not meet the criteria of the author to represent this research. 


\subsection{Research Data}

The data collection method for this research is to process secondary data such as summary data on the financial performance of companies in the trade, services and investment sectors listed in JII from the official website www.idx.co.id, historical data on inflation rates and the BI Rate from this website. www.bi.go.id and www.bps.go.id. And also using documentation techniques or conducting literature studies, which is one of the data collection techniques to trace historical data. In this study, the authors searched for data by looking at the annual financial reports of issuers listed on the Jakarta Islamic Index (JII), data collected and processed in the form of information regarding dividends, market capitalization, market value ratios during the period 2014 to 2018 .

\subsection{Research Variables}

The variables in this research model are the independent (free) and dependent (dependent) variables. Independent variables (variables that influence) are described by the inflation rate, interest rate (BI Rate), market capitalization, PER and PBV. The dependent variable (the variable that is influenced) is the return of Islamic stocks.

\section{RESULTS AND DISCUSSION}

Descriptive statistics aim to provide an overview of the state of each research variable, which is described in Table 4.

Based on Table 4, the independent variable research description will present an overview of each independent variable to be analyzed.

\section{Inflation Rate}

Inflation has an important role in the reference for estimating the value of investment to predict how much the return on investment will be. The inflation rate can affect the value of currency, investment and savings so that it has a risk of decreasing return on investment (return), inflation can be said to be maintained and under control if it is still within the target set by the Central Bank. Based on table 4, the results of the descriptive statistical test show the lowest (minimum) inflation rate of $3.02 \%$, namely 2016 and a maximum value of $8.36 \%$ in 2014 , the average value (mean) of $4.29 \%$ during the study period with a standard deviation of $2.12 \%$.

2. Interest Rate (BI Rate)

In table 4 the results of the descriptive statistical test show the lowest (minimum) interest rate is $4.56 \%$ in 2017, the maximum value is $7.53 \%$ in 2014 , the average (mean) is $6.14 \%$ during the study period with a standard deviation of $1.26 \%$. If seen from Table 4 , it is found that the highest interest rate and inflation occurred in 2014, this was due to the high increase in the price of fuel oil (BBM) in 2014 which resulted in an increase in inflation and interest rates. The interest rate will usually affect the responsibility for the cost of capital by the company, and if the interest rate is high, it will affect the actual return an investor or shareholder gets in a security.

3. Market Capitalization

Descriptive statistical data table 4 provides an overview of the market capitalization variable as X3 during the study period. The results of the descriptive statistical test show that the lowest (minimum) market capitalization amount is IDR 16,124,187,217 owned by PT AKR Corporindo Tbk in 2014, the highest value (maximum) of IDR 132,046,784,000 is owned by PT United Tractors Tbk in 2017, while the average -The average (mean) is IDR 50,226,295,937 during the study period with a standard deviation of IDR $33,236,555,923$. Market capitalization itself is the value of a company's shares issued in the market, which shows the total price of a company if someone wants to buy $100 \%$ of its ownership. Usually large cap stocks tend to attract investors to buy their shares because they are considered capable of providing optimal returns for their shareholders. In this study, the company in the trade, service and investment sector that can provide optimal returns and is most attractive to investors when viewed from its market capitalization is the company United Tractors.

4. Price Earning Ratio (PER)

The PER value shows the market value and also reflects the fundamentals of a company, a high PER value indicates the company's stock price is getting higher in the market. Investors hope that the high PER value, which shows the good fundamentals of the company, can also generate profits that will grow so that the return on the shares purchased is obtained faster than the estimated PER value. Because the PER value shows how many years the investment (stock return) will return on investment. Based on table 4, the results of the descriptive statistical test show the lowest PER (minimum) of 8.43 in 2018, namely PT United Tractors Tbk, the highest (maximum) value of 35.17 in 2014, namely PT Surya Citra Media Tbk, while the average (mean) is 21.02 during the study period with a standard deviation of 7.68 . The PER value in 2018 of the three companies decreased significantly, the average in 2018 was 12.78 while in the previous year it was 22.16.

5. Price Book Value (PBV)

PBV is often used to assess whether a company's stock price falls into the expensive or cheap category, a large PBV value indicates that the stock price is getting more expensive, but usually a good company has a large PBV, because the company is considered capable of managing its assets to produce greater company value. However, the PBV value is low, which indicates that the company's stock price is cheap, if the share price is below its book value, there is a tendency for the stock price to go to balance, at least equal to its book value and the stock price has great potential to increase, meaning that the return will 
be obtained in the future will be greater. Based on table 4 , the descriptive statistical test results show the lowest PBV (minimum) of 1.

In Table 5 data, the return of Islamic stocks in the trade, services and investment sector companies in JII shows a fluctuating return movement in each company every year from 2014 to 2018. The stock that gave the highest return was AKR Corporindo Tbk company in 2015 but in the year- the following year until 2018 the rate of return continued to decline even to a negative value of $-32 \%$ in 2018 which is the smallest return during the study period. Overall, United Tractors Tbk's shares are the issuer that provides the highest return with an average return of $12 \%$. Meanwhile, the company that has the lowest return with an average of $-5 \%$ is Surya Citra Media Tbk. Stock returns, which tend to experience a downward trend every year to a negative value, can also give negative signals to investors, because this illustrates that investors will experience losses if they invest their funds in the company. A fairly high decline occurred in 2018, where the three companies fell and even had a negative value in the same year with the average return in 2017 reaching $-27 \%$.

\subsection{Multiple Linear Regression Analysis}

From Table 6, the coefficient for the inflation rate independent variable is 0.206 , the interest rate variable is 0.033 , the market capitalization variable is 6.380 , the PER variable is 0.51 and the PBV variable is -0.66 , based on the test results in table 6 above, it is obtained the regression equation in this study is as follows:

Return Saham Syariah $(\mathrm{Y})=-1.337+0.22 \mathrm{X} 12$

$+0.029 X 345+6.654 X+0.053 X-0.068 X$

The regression equation model above can be explained as follows:

a. The constant is negative, it shows that when all the values of the independent variables (Inflation Rate, Interest Rate, Market Capitalization, PER and PBV) are constant or fixed, the return value will decrease by 1.337. -1.337

b. The value of the inflation rate coefficient $(\beta X 1)$ is with a positive value. This shows that every increase that occurs in inflation by 1 unit, the return of Islamic stocks also increases by 0.22 with the assumption that other variables are of fixed value 0.22 .

Table 4. Descriptive Statistics Test Results

\begin{tabular}{lccccc}
\hline & $\mathrm{N}$ & Minimum & Maximum & Mean & Std. Deviation \\
\hline Return & 15 & -32 & 74 & 4 & 32 \\
Inflation Rate & 15 & 3.02 & 8.36 & 42.940 & 211.471 \\
Interest Rate & 15 & 4.56 & 7.23 & 61.400 & 126.392 \\
Capitalization & & 16.124 & 132.046 & 502.260 & 33.236 \\
& 15 & 187.217 & .784 .000 & .295 .937 & .555 .923 \\
PER & 15 & 8.43 & 35.17 & 210.200 & 767.795 \\
PBV & 15 & 1.61 & 14.67 & 50.140 & 434.199 \\
Valid N (Listwise) & 15 & & & & \\
\hline
\end{tabular}

Table 5 Sharia Stock Return Data for Trade, Services \& Investment Companies in JII during the 2014-2018 Period

\begin{tabular}{cccccccc}
\hline \multirow{2}{*}{ No } & \multirow{2}{*}{ Company Code } & \multicolumn{7}{c}{ Return } \\
\cline { 3 - 8 } & & 2014 & 2015 & 2016 & 2017 & 2018 & Average \\
\hline 1 & AKRA & $-6 \%$ & $74 \%$ & $-16 \%$ & $6 \%$ & $-32 \%$ & $5 \%$ \\
2 & UNTR & $-9 \%$ & $-2 \%$ & $25 \%$ & $67 \%$ & $-23 \%$ & $12 \%$ \\
3 & SCMA & $33 \%$ & $-11 \%$ & $-10 \%$ & $-11 \%$ & $-25 \%$ & $-5 \%$ \\
& Average & $6 \%$ & $20 \%$ & $0 \%$ & $20 \%$ & $-27 \%$ & \\
\hline
\end{tabular}


Table 6 Multiple Linear Regression Test Results

\begin{tabular}{lccccc}
\hline & \multicolumn{3}{c}{ Unstandardized Coefficients } & & \\
\cline { 2 - 4 } Model & $\mathrm{B}$ & Std. Error & Beta & T & Sig. \\
\hline Return & -1.337 & 400 & - & -3.347 & .009 \\
Inflation Rate & .022 & .035 & .144 & .620 & .550 \\
Interest Rate & .029 & .060 & .113 & .479 & .644 \\
Capitalization & 6.654 & .000 & .690 & 3.347 & .009 \\
PER & .053 & 0.53 & 1.272 & 3.637 & .005 \\
PBV & .068 & .025 & .025 & -2.776 & .002 \\
\hline
\end{tabular}

c. Interest Rate Coefficient Value $(\beta X 2)$ is 0.029 with a positive value. This explains that every time there is an increase in the BI Rate by 1 unit, the return on Islamic stocks will also increase by 0.029 with the assumption that other variables are of fixed value.

d. Market Capitalization coefficient value $(\beta X 3)$ is 6,654 with a positive value. This shows that every time there is an increase in Market Capitalization by 1 unit, the return on Islamic stocks will increase by 6,654 with the assumption that other variables are of fixed value.

e. PER coefficient value $(\beta X 4)$ is 0.053 with a positive value. This shows that every time there is an increase in PER by 1 unit, the return of Islamic stocks will increase by 0.053 with the assumption that other variables are of fixed value.

f. PBV coefficient value $(\beta X 5)$ is -0.068 with a negative value. This shows that every time there is an increase in PBV of 1 unit, the return of Islamic stocks will decrease by 0.068 , assuming other variables are of fixed value.

\subsection{Test of the coefficient of determination}

Based on Table 7 above shows an $\mathrm{R}$ value of 0.824 which indicates the two macroeconomic variables and the three fundamental variables of the company, namely inflation, BI Rate, market capitalization, PER and PBV have a strong correlation to Islamic stock returns, the greater the $\mathrm{R}$ value, the stronger the correlation between the five the independent variable with the dependent variable, the number $\mathrm{R}$ which is positive indicates a positive correlation. So that together when all the independent variables increase, it will increase the return, or vice versa. But this still cannot indicate a causal correlation between the five independent variables and the dependent variable, because the correlation only explains the level of the relationship. Therefore, Adjusted R-Square is used to see the increase or decrease in value when one independent variable is added or subtracted from the research model. From table 7 above, the Adjusted R-Square value obtained is 0.501 . These results indicate that all independent variables in the research model can explain the dependent variable by $50.1 \%$, while the remaining $49.9 \%$ are explained by other factors outside the model in this research model.

Table 7. Determination Coefficient Test Results

\begin{tabular}{lcccc}
\hline Model & R & R Square & $\begin{array}{c}\text { Adjusted R } \\
\text { Square }\end{array}$ & $\begin{array}{c}\text { Std. Error of } \\
\text { the Estimate }\end{array}$ \\
\hline 1 & $.824^{\mathrm{a}}$ & .679 & .501 & .22638 \\
\hline a.Predictors: (Constant), PBV, Inflation Rate, Interest Rate, \\
Capitalization, PER. \\
b. Dependent Variable: Return.
\end{tabular}

\section{3 t test (partial)}

Table 8 shows that partially independent variables are able to influence significantly and some are not significant to return. This is indicated by the significance value $(\mathrm{Sig})$ of variable $\mathrm{X} 1$ is 0.550 or $55 \%>5 \%$ with a positive value meaning that the inflation rate has no significant effect on sharia stock returns, for variable X2 it is 0.644 or $64.4 \%$ > $5 \%$ with a positive value meaning the level of Interest rates have an insignificant effect on Islamic stock returns, variable $\mathrm{X} 3$ is 0.009 or $0.9 \%$ with a positive value $<5 \%$, it means that market capitalization has a significant effect on Islamic stock returns, variable X4 is 0.005 or $0.5 \%<5 \%$ with a positive value means that PER has a significant effect on sharia stock returns and the X5 variable is 0.022 or $2.2 \%<5 \%$, meaning that PBV has a significant effect on Islamic stock returns with a negative value. It can be concluded that the macroeconomic variables indicated by the inflation rate and the interest rate have insignificant results because of the Sig. $>0.05$ or $5 \%$. 
Table 8 Partial Test Result (t test)

\begin{tabular}{lcccc}
\hline Variable & Value of $\mathrm{t}$ & Sig value. & $\alpha$ (level of significant) & Result \\
\hline Inflation Rate & .620 & 0.550 & 0.05 & Not significant \\
& & & & \\
Interest Rate & .479 & 0.644 & 0.05 & Not significant \\
Market Capitalization & 3,347 & 0.009 & 0.05 & Significant \\
PER & 3,637 & 0.005 & 0.05 & Significant \\
PBV & $-2,776$ & 0.022 & 0.05 & Significant \\
Significance Level $(\alpha=5 \%)$ & & & &
\end{tabular}

Table 9 Simultaneous Test Results (Test F)

\begin{tabular}{|c|c|c|c|c|c|c|}
\hline & Model & Sum of Squares & Df & Mean Square & $\mathrm{F}$ & Sig. \\
\hline \multirow{3}{*}{1} & Regression & .976 & 5 & .195 & 3.809 & $.039^{b}$ \\
\hline & Residual & .461 & 9 & .051 & & \\
\hline & Total & 1.437 & 14 & & & \\
\hline
\end{tabular}

a.Predictors: (Constant), PBV, Inflation Rate, Interest Rate, Capitalization, PER.

b.Dependent Variable: Return.

\begin{abstract}
Meanwhile, the company's fundamental variables, namely market capitalization, PER and PBV individually (partially) have a significant effect because of the Sig. $<0.05$ or $5 \%$. It can be concluded that the macroeconomic variables indicated by the inflation rate and the interest rate have insignificant results because of the Sig. > 0.05 or $5 \%$. Meanwhile, the company's fundamental variables, namely market capitalization, PER and PBV individually (partially) have a significant effect because of the Sig. $<0.05$ or $5 \%$. It can be concluded that the macroeconomic variables indicated by the inflation rate and the interest rate have insignificant results because of the Sig. $>0.05$ or $5 \%$. Meanwhile, the company's fundamental variables, namely market capitalization, PER and PBV individually (partially) have a significant effect because of the Sig. $<0.05$ or $5 \%$.
\end{abstract}

\subsection{F Test (Simultaneous)}

Based on the test results in table 9 above, the Sig. obtained in the ANOVA table amounted to $0.039 \mathrm{~b}$. Because the Sig. 0.039 which means less than 0.05 , it can be concluded simultaneously the variables $\mathrm{X} 1, \mathrm{X} 2, \mathrm{X} 3, \mathrm{X} 4$ and $\mathrm{X} 5$ have a significant effect on $\mathrm{Y}$.

\subsection{Research Discussion}

1. The Influence of Inflation Rate on Sharia Stock Return

The results of this study indicate that the inflation rate (X1) partially has a positive and insignificant effect on Sharia Stock Return because it has a regression coefficient value of 0.022 , the result of the $t$ statistical test is 0.620 with a significance level of 0.550 , because the sig value $(0.550)>0.05$ and The regression coefficient value has a positive value, then $\mathrm{H} 1$ is rejected, that is, inflation has a negative effect on Islamic stock returns. This indicates that when the rate of inflation has increased, the return on shares of sharia companies in the trade, services and investment sectors will increase. But the significance level> 0.05 or $5 \%$ indicates that the effect of changes in the inflation rate does not really influence (not significant) on the activity of Sharia stock returns in trade, services and investment sector companies in JII. Because the research was conducted on the types of Islamic stocks, companies that are included in the category and the Islamic stock index usually do not really take into account high profits, but prioritize mutual benefit. Based on the theory, Islamic stocks aim to maintain the stability of returns when the economy is uncertain so that the return on Islamic stocks tends to be smaller than conventional stock 
returns, which states that inflation has an effect on sharia stock returns partially.

2. Effect of Interest Rate (BI Rate) on Sharia Stock Return

The analysis in this study shows the results that the interest rate (X2) partially has a positive and insignificant effect on Sharia Stock Returns, because it has a regression coefficient value shown is 0.029 , the $t$ statistical test value is 0.479 with a significance value of 0.644 . Because the correlation coefficient is positive and the sig value $(0.644)>0.05$ then $\mathrm{H} 2$ is rejected, that is, there is a negative effect on sharia stock returns. This means that when there is an increase in the value of interest rates, the return on shares of Islamic companies in the trade, services and investment sectors will increase. But a significance value of more than 0.05 or $5 \%$ indicates that the effect of changes in the inflation rate does not really affect the activity of sharia stock returns (not significant) in trade, services and investment sector companies in JII, so changes that occur in the interest rate (BI Rate) do not significantly affect or too drastically on stock returns. Because companies that are included in the category and the Islamic stock index, one of which is JII is usually stable because it is included in the 30 most liquid Islamic stocks category. This indicates that the macroeconomic factors in this study, namely inflation and interest rates, do not have a significant effect on sharia stock returns, but for further research this variable can still be used to be re-examined because it still has a positive effect. Because companies that are included in the category and the Islamic stock index, one of which is JII is usually stable because it is included in the 30 most liquid Islamic stocks category. This indicates that the macroeconomic factors in this study, namely inflation and interest rates, do not have a significant effect on sharia stock returns.

3. The Effect of Market Capitalization on Sharia Stock Return

The results of this study indicate that market capitalization (X3) partially has a significant positive effect on Sharia Stock Return, because it shows the regression coefficient value of 6,654 and the $t$ statistical test value of 3,347 with a significance value of 0.009 . The correlation coefficient is positive and the sig value $(0.009)<0.05$ indicates that $\mathrm{H} 3$ is accepted, that is, there is a positive influence on Islamic stock returns. When market capitalization has increased, the return on shares of sharia companies in the trade, services and investment sectors will also increase. The significance value> 0.05 or $5 \%$ indicates that the effect of changes in market capitalization will greatly affect the activity of sharia stock returns (significant) in trade, services and investment sector companies on the JII index.

Companies that have a large market capitalization with high market value indicate that these shares are included in the category of leading stocks in the capital market so they are often the target of investors.

4. Effect of Price Earning Ratio (PER) on Sharia Stock Return

The results of the analysis in this study indicate that PER (X4) partially has a positive and significant effect on Sharia Stock Return, because it has a regression coefficient value of 0.053 , the t statistical test value is 3,637 with a significance level of 0.005 . The correlation coefficient is positive and the sig value $(0.005)<0.05$ indicates that $\mathrm{H} 4$ is accepted, that is, there is a positive influence on Islamic stock returns. This means that when the PER value has increased, the return of Islamic stocks in trade, services and investment companies will also increase and vice versa. The significance value $>0.05$ or $5 \%$ indicates that the effect of changes in the PER value will greatly affect the activity of sharia stock returns (significant) in trade, services and investment sector companies in JII. That matter,

5. Effect of Price Book Value (PBV) on Sharia Stock Return

This study suggests that PBV (X5) partially has a negative and significant effect on Sharia Stock Return, because based on the results of the regression coefficient value shows the number -0.068 , the statistical t-test number is -2.776 with a significance value of 0.022 . Because the value of the correlation coefficient is negative and the sig value $(0.022)$ $<0.05, \mathrm{H} 5$ is accepted, that is, there is a negative effect on Islamic stock returns. This indicates that if there is an increase in PBV value, it is not always followed by an increase in return on Islamic stocks in trade, services and investment companies in JII. A significance value of less than 0.05 or $5 \%$ indicates that the effect of changes in the PBV value will greatly affect the activity of sharia stock returns (significant) in trade, services and investment sector companies in JII just in the opposite direction. This indicates that a high PBV value does not always attract investors to the company even though generally a PBV value $(>1)$ indicates that the company is operating well. A PBV ratio that is too high can be a signal to investors that the company is too expensive or not worth the return it provides.

Based on the results of this study, it shows that a high PBV does not always indicate a high assessment of investors, because a stock price that is too high does not always provide a high return as well.

6. The Influence of Inflation Rate, BI Rate, Market Capitalization, PER and PBV on Sharia Stock Return. The results of the F test (simultaneous) in table 9 show that the variable rate of inflation, interest rates, market capitalization, Price Earning Ratio (PER) and Price Book Value (PBV) has a significant influence on the return variable of Islamic stocks, because the results of the $\mathrm{F}$ test show value 3.809 using a 
significance level of $0.039<0.05$. Then H6 is accepted, that is, there is a significant influence between the inflation rate, interest rate (BI Rate), market capitalization, PER and PBV on the return of Islamic stocks in trade, services and investment companies in JII 2014-2018 period. This indicates that a simultaneous increase in inflation, BI Rate, PER and PBV can cause an increase in returns, and vice versa.

\section{CONCLUSIONS}

The results of the study partially show that there is an insignificant influence from macroeconomic factors as indicated by the inflation rate and the BI Rate, while there is a significant influence on company fundamental factors as indicated by market capitalization and market financial ratios, namely Price Earning Ratio (PER) and Price Book Value (PBV) on the return of Islamic stocks in trade, services and investment sector companies listed in JII, where the companies sampled in this study are AKR Corporindo Tbk, United Tractors Tbk and Surya Citra Media Tbk. This research supports the theory which states that investing in Islamic instruments should not only be speculative in order to obtain high returns in the short term, because in addition to having to know as a whole the company that will be the object of investment, Islamic investors must be ready to bear the risks that will occur and also get a lower return than conventional stocks because returns on Islamic instruments have anticipated that returns remain stable in the event of economic instability, because one of the principles of Islamic stocks is the benefit of the people / customers. Simultaneously it shows that there is still an influence of $50.1 \%$, which means that if there is a drastic deflation or decrease in interest rates it will also decrease returns, because the effect is positive so it can be said that it is still influential, it's just not too dominant. The research also supports the theory that the greater the market capitalization and PER of a company will have an impact on increasing sharia stock returns, and the size of the PBV does not always have an impact on investor interest, because investors think that high stock valuations will make return on investment even longer. This shows that positive information about the company's fundamentals can give a positive signal to Islamic investors as well. Islamic investors are advised to get to know the companies that will be the target of their sharia investment by analyzing more deeply the company's fundamentals, so that they are not only speculative by looking at the development of company returns. For the next research that will examine Islamic stocks, you should not limit it to certain sectors to be more accurate. and the size of the PBV does not always have an impact on investor interest, because investors think that a high stock valuation will make a return on investment even longer. This shows that positive information about the company's fundamentals can give a positive signal to Islamic investors as well. Islamic investors are advised to get to know the companies that will be the target of their sharia investment by analyzing more deeply the company's fundamentals, so that they are not only speculative by looking at the development of company returns. For the next research that will examine Islamic stocks, you should not limit it to certain sectors to make it more accurate. and the size of the PBV does not always have an impact on investor interest, because investors think that a high stock valuation will make a return on investment even longer. This shows that positive information about the company's fundamentals can give a positive signal to Islamic investors as well. Islamic investors are advised to get to know the companies that will be the target of their sharia investment by analyzing more deeply the company's fundamentals, so that they are not only speculative by looking at the development of company returns. For the next research that will examine Islamic stocks, you should not limit it to certain sectors to be more accurate. This shows that positive information about the company's fundamentals can give a positive signal to Islamic investors as well. Islamic investors are advised to get to know the companies that will be the target of their sharia investment by analyzing more deeply the company's fundamentals, so that they are not only speculative by looking at the development of company returns. For the next research that will examine Islamic stocks, you should not limit it to certain sectors to make it more accurate. This shows that positive information about the company's fundamentals can give a positive signal to Islamic investors as well. Islamic investors are advised to get to know the companies that will be the target of their sharia investment by analyzing more deeply the company's fundamentals, so that they are not only speculative by looking at the development of company returns. For the next research that will examine Islamic stocks, you should not limit it to certain sectors to make it more accurate. so that it is not only speculative by looking at the development of company returns alone. For the next research that will examine Islamic stocks, you should not limit it to certain sectors to be more accurate. so that it is not only speculative by looking at the development of company returns alone. For the next research that will examine Islamic stocks, you should not limit it to certain sectors to be more accurate.

\section{REFERENCES}

[1] A. N. Ajmi, S. Hammoudeh, D. K. Nguyen, S. Sarafrazi. How strong are the causal relationships between Islamic stock markets and conventional financial systems? Evidence from linear and nonlinear tests. Journal of International Financial Markets, Institutions and Money, 28 (2014) 213-227. DOI: https://doi.org/10.1016/j.intfin.2013.11.004

[2] D. Harvie, R. Ogman. The broken promises of the social investment market. Environment and Planning A: Economy and Space, 51 (4) (2019) 980-1004. DOI: https://doi.org/10.1177/0308518X19827298 
[3] R. Hasan, M. Moore, R. Handfield. Addressing social issues in commodity markets: Using cost modeling as an enabler of public policy in the Bangladeshi apparel industry. Journal of Supply Chain Management, 56 (4) (2020) 25-44. DOI: https://doi.or $\mathrm{g} / 10.1111 / \mathrm{jscm} .12228$

[4] D. Shah, H. Isah, F. Zulkernine. Stock market analysis: A review and taxonomy of prediction techniques. International Journal of Financial Studies, 7(2) (2019) 26-36. DOI: https://doi.org/10.339 0/ijfs7020026

[5] S. Chakraborty, S. K. Saha, S. A. Selim. Recreational services in tourism dominated coastal ecosystems: Bringing the non-economic values into focus. Journal of Outdoor Recreation and Tourism, 30 (2020) 100279. DOI :https://doi.org/10.1016/j.jort.2020 .100279

[6] Y. Yunita, R. Robiyanto. The Influence of Inflation Rate, Bi Rate, and Exchange Rate Changes To the Financial Sector Stock Price Index Return in the Indonesian Stock Market. Jurnal Manajemen Dan Kewirausahaan, 20 (2) (2018) 80-86. DOI: https://doi. org/10.9744/jmk.20.2.80-86

[7] E. Yang, S. H. Kim, M. H. Kim, D. Ryu. Macroeconomic shocks and stock market returns: The case of Korea. Applied Economics, 50 (7) (2018) 757773. DOI: https://doi.org/10.1080/00036846.2017.1340 574

[8] C. Lian, Y. Ma, C. Wang. Low interest rates and risk-taking: Evidence from individual investment decisions. The Review of Financial Studies, 32 (6) (2019) 2107-2148. DOI: https://doi.org/10.1093/rfs/hh y111

[9] J. Jefry, A. Djazuli. The Effect of Inflation, Interest Rates and Exchange Rates on Stock Prices of Manufacturing Companies in Basic and Chemical Industrial Sectors on the Indonesia Stock Exchange (IDX). International Journal of Business, Management \& Economics Research, 1(1) (2020) 34-49. DOI: https: //doi.org/10.47747/ijbmer.v1i1.49
[10] P. E. Campana, L. Wästhage, W. Nookuea, Y. Tan, J. Yan. Optimization and assessment of floating and floating-tracking PV systems integrated in on-and offgrid hybrid energy systems. Solar Energy, 177 (2019) 782-795. DOI: https://doi.org/10.1016/j.solener.2018.1 1.045

[11] T. L.Sha. Effects of price earnings ratio, earnings Per share, book to market ratio and gross domestic product on stock prices of property and real estate companies in Indonesia stock exchange. Journal of Economic \& Management Perspectives, 11 (1) (2017) $1743-1754$

[12] F. Alessandrini, E. Jondeau. ESG investing: From sin stocks to smart beta. The Journal of Portfolio Management, 46 (3) (2020) 75-94. DOI: https://doi.org $/ 10.3905 / \mathrm{jpm} .2020 .46 .3 .075$

[13] W. Hadi. Analysis of the effect of net profit margin, return on assets and return on equity on stock price (Case study on consumption industrial sector companies listed in Indonesian Sharia Stock Index at Indonesia Stock Exchange in 2016). The Management Journal of Binaniaga, 3 (02) (2018) 81-92.

[14] I. Fahmi, Analisis Laporan Keuangan. Bandung: Alfabeta, 2017

[15] Abdalloh, Irwan. Pasar Modal Syariah. Jakarta: PT Elex Media Komputindo. 2018

[16] Hasnawati, S. (2020). Board Diversity and Profitability in Small-Capitalization Companies Listed on the Indonesia Stock Exchange. Journal of Economics and Finance, 11(6), 55-63. DOI: https:// doi.org/10.9790/5933-1106035563

[17] D. Darmawan. Metode Penelitian Kuantitatif. Bandung: Rosda, 2014.

[18] Sugiyono. Metode Penelitian Kuantitatif, Kualitatif, dan R\&D. Bandung: Alfabeta 2015. 